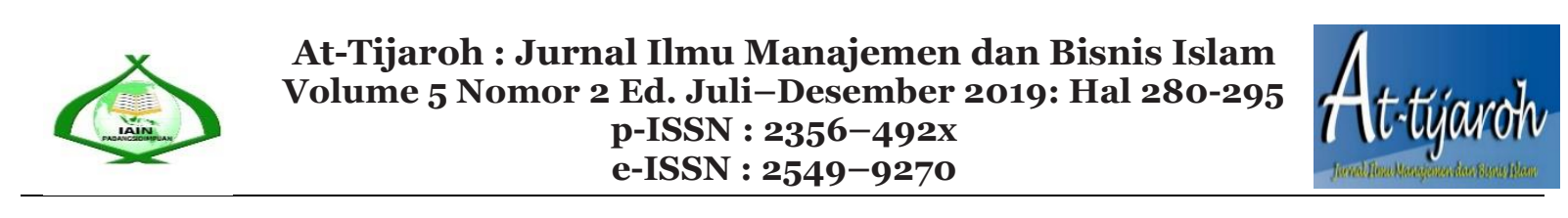

\title{
CITRA PERUSAHAAN, KUALITAS PELAYANAN DAN SALURAN DISTRIBUSI TERHADAP KEPUASAN NASABAH
}

\author{
Rokhmat Subagiyo ${ }^{1}$, Ahmad Budiman² \\ Institut Agama Islam Negeri Tulungagung \\ JL. Mayor Sujadi Timur 46 Tulungagung, Jawa Timur ${ }^{12}$ \\ E-mail : rokhmatsubagyo@iain-Tulungagung.ac.id ${ }^{1}$, abudiman507@gmail.com²$^{2}$,
}

\begin{abstract}
Every company activity must be adjusted. Every change in the business environment is fast and accurate. Bank Syariah Mandiri Financing Bank (BPRS) successfully conducted fundraising activities and channeled funds to the public. There are some things that are more satisfying than expected by the company, quality of service and distribution. The purpose of this study was to examine the effect of significant company funds on Customer Satisfaction, assess the importance of good service to Customer Satisfaction and obtain a significant distribution channel to Customer Satisfaction. The research method uses quantitative research and associative research types. Data analysis techniques cursed multiple linear regression analysis using SPSS version 23. The results showed that company image has a significant effect on customer satisfaction, service quality is significantly related to sales satisfaction and distribution distribution significantly on customer satisfaction.
\end{abstract}

Keywords: Company Image, Service Quality, Customer Satisfaction

\begin{abstract}
Abstrak
Setiap kegiatan perusahaan bisnis harus mampu mengadopsi setiap perubahan dalam lingkungan bisnis secara cepat dan akurat. Bank Pembiayaan Syariah (BPRS) Mandiri Mitra sukses melakukan kegiatan penghimpunan dana dan menyalurkan dana kepada masyarakat. Ada beberapa hal yang mempengaruhi kepuasan nasabah diantaranya adalah citra perusahaan, kualita pelayanan dan saluran distribusi. Tujuan penelitian ini untuk menguji pengaruh signifikan dana Citra perusahaan terhadap Kepuasan Nasabah, menguji pengaruh signifikan Kualitas Pelayanan terhadap Kepuasan Nasabah dan menguji Saluran Distribusi berpengaruh signifikan terhadap Kepuasan Nasabah. Metode penelitian menggunakan penelitian kuantitatif dan jenis penelitian asosiatif. Teknik analisis data memaki analisis regresi linier berganda dengan menggunakan aplikasi SPSS versi 23. Hasil penelitian menunjukkan bahwa citra perusahaan berpengaruh signifikan terhadap kepuasan nasabah, kualitas pelayanan berpengaruh signifikan terhadap kepuasan nasabah dan saluran distribusi berpengaruh signifikan terhadap kepuasan nasabah.
\end{abstract}

Kata Kunci: Citra Perusahaan, Kualitas Pelayanan, Kepuasan Nasabah 


\section{1 |Citra Perusahaan, Kualitas Pelayanan dan Saluran Distribusi Terhadap Kepuasan Nasabah}

\section{PENDAHULUAN}

Era milenial saat ini dengan tingkat persaingan yang ketat, harus mampu menjadikan Indonesia sebagai negara yang berdaulat dengan negara-negara pesaingnya. Sebagai salah satu negara berkembang, Indonesia harus memperhatikan pondasi ekonomi agar selalu kuat. Dengan perekonomian yang kokoh akan menjadikan Indonesia sebagai negara yang disegani dalam perdagangan internasional. Salah satu penyumbang perekonomian sebuah negara kuat adalah keberadaan perusahaan bisnis.

Perusahaan dituntut untuk selalu mengambil sikap dan tindakan yang bisa mengikuti perubahan dalam lingkungan bisnis yang selalu berubah dengan cepat dengan ketidakpastian. Kondisi ini menyebabkan perusahaan harus untuk selalu mampu menciptakan dan membuat terobosan-terobosan agar konsumen tetap loyal dan diantaranya melaui persaingan antar merek. Harapannya perusahaan bisa memenangkan perang antar merek tersebut.

Banyak perusahaan yang lebih menekankan pada citra sebagai daya tarik perusahaan untuk menggaet investor yang akan berefek positif bagai masyarakat sekitarnya, untuk menghilangkan kesan negatif. Atau bisa juga dikatakan bahwa citra perusahaan adalah komoditas yang sangat rentan berubah. Dengan demikian perusahaan saat ini mulai memperbaiki diri secara jangka panjang agar mampu terus bertahan.

Pendapat Bill Canton dalam (Bajra, Arifin, \& Sunarti, 2015) citra adalah "Image the Impression the Feeling, the Conception of an objek, person or Organitation" (citra adalah kesan, perasaan, gambaran dari pubik terhadap perusahaan, kesan yang dengan sengaja diciptakan dari suatu objek, orang atau organisasi)

Citra perusahaan merupakan kesan yang didapat seseorang berdasarkan pemahaman atas pengetahuan yang dimilikinya mengenai sebuah perusahaan. Jadi atau tidaknya konsumen membeli sebuah produk atau jasa, tidak hanya didasarkan atas kebutuhan semata, namun ada sesuatu lain yang diharapkannya. Sesuai yang lain itu diharapkan sesuai dengan citra yang membentuk dalam dirinya. Dengan demikian penting sekali organisasi memberikan informasi kepada publik supaya citra yang baik bisa terwujud (Alma, 2013).

Citra perusahaan dipengaruhi oleh empat (4) faktor yaitu: (1) lambang, Citra dapat diperkuat dengan menggunakan simbol-simbol yang kuat. Sebagaimana yang kita kenal dalam dunia Informasi dan Teknologi misalnya, Apple Computer yang telah memilih simbol "Apel” untuk produknya; (2) media, Citra yang dipilih harus ditampilkan dalam iklan yang menyampaikan suatu cerita, suasana hati, pernyataan sesuatu yang jelas berbeda dengan yang lain. Pesan itu harus tampak di laporan tahunan, brosur dan katalog, peralatan kantor perusahaan, serta kartu nama; (3) suasana, Suatu bank yang ingin tampak ramah harus memilih rancangan gedung, rancangan interior, tata letak, warna, material, dan perabotan yang tepat dan (4) peristiwa, Suatu perusahaan dapat membangun suatu identitas melalui jenis kegiatan yang disponsorinya (Kotler \& Armstrong, 2008). 
Saat ini bisnis yang mendominasi perannya terhadap dunia ekonomi keberadaan lembaga keuangan perbankan. Perbankan salah satu fungsinya sebagai lembaga intermediasi, maksudnya menyalurkan uang dari pemilik uang kepada orang atau badan usaha yang membutuhkan akan menopang tingkat perkonomian sebuah bangsa. Adanya perbankan membantu masyarakat dalam menentukan keputusan bisnis sehingga kegiatan perekonomian tumbuh.

Industri jasa ada dimana-mana yang meliputi sektor pemerintah dengan pengadilan, jasa penyedia lapangan kerja, rumah sakit, lembaga pinjaman, jasa militer, kepolisian dan pemadam kebakaran, jasa pos, lembaga peraturan, dan sekolah, adalah bisnis jasa (Kotler, 2012). Sektor nirlaba swasta dengan museum, lembaga amal, gereja, perguruan tinggi, yayasan, dan rumah sakit, merupakan bisnis jasa. Banyak pekerja di sektor manufaktur seperti operator komputer, akuntan, dan staf hukum, sebenarnya merupakan penyedia jasa. Bahkan mereka membentuk "pabrik jasa” yang menyediakan jasa bagi "pabrik barang." Dan pekerja di sektor eceran seperti kasir, pegawai toko, wiraniaga, dan perwakilan layanan pelanggan, juga menyediakan jasa.

Bank Pembiayaan Syariah (BPRS) Mandiri Mitra sukses atau lebih dikenal oleh masyarakat dengan sebutan Bank Mitra Syariah melakukan kegiatan penghimpunan dana dan menyalurkan dana kepada masyarakat. Salah satu produk simpanannya berwujud tabungan simitra mikro, yang memberikan banyak keuntungan yaitu bisa dijadikan sebagai jaminan dalam pengajuan pembiyaan sekaligus juga sebagai salah satu syarat untuk mengajukan pembiayaan. Dengan demikian perbandingan jumlah nasabah penabung dan nasabah pembiayaan berbanding lurus. Sebagai salah satu faktor yang memiliki pengaruh terhadap kelangsungan operasional bank adalah nasabah penabung.

Beberapa hal yang mempengaruhi kepuasan nasabah diantaranya adalah citra perusahaan. Citra perusahaan sebagai kesan keseluruhan yang muncul dalam pikiran masyarakat tentang suatu organisasi. Menurut Jefkins, citra perusahaan sebagai Citra dari suatu organisasi secara keseluruhan, bukan hanya citra atas produk dan pelayanan saja (Soemirat \& Ardianto, 2007). Dianggap sebagai salah satu faktor utamg yang berpengaruh terhadap penilaian kualitas, evaluasi kepuasan pelanggan dengan layanan serta loyalitas pelanggan ketika layanan sulit untuk dievaluasi. Citra perusahaan merupakan suatu isyarat informasi ekstrinsik untuk pembeli yang sudah ada maupun yang potensial dan secara mungkin atau tidak mungkin dapat mempengaruhi loyalitas pelanggan (Andreassen, 1994).

Pada sebuah retail kualitas pelayanan sangat penting dalam memberikan kepuasan pelanggan, mempertahankan pelanggan dan menciptakan loyalitas pelanggan (Subagiyo \& Adlan, 2017). Langkah yang diambil agar pelanggan memperoleh kepuasan adalah dengan mengidentifikasi dan memberikan layanan produk atau jasa yang dibutuhkan pelanggan. 


\section{3 |Citra Perusahaan, Kualitas Pelayanan dan Saluran Distribusi Terhadap Kepuasan Nasabah}

Kualitas pelayanan sangat penting bagi suatu perusahaan untuk dapat mempertahankan pangsa pasar dan meningkatkan profitabilitas dalam persaingan bisnis yang sengit.

Pelanggan yang memperoleh kepuasan akan bermanfaat bagi perusahaan, antara lain tidak memperdulikan harga, berbicara kepada orang lain tentang kebaikan perusahaan dan produk-produknya, dan tetap setia untuk periode yang lebih lama. Oleh sebab itu sangatlah penting untuk membangun kesetiaan pelanggan dengan menciptakan kepuasan pelanggan (Haryono, 2015).

Struktur yang mendeskripsikan banyak pilihan saluran dan situasi pemasaran yang berlainan berbagai perusahaan. Distributor atau perantara melakukan distribusi produk dengan cara penawaran langsung kepada konsumen atau pelanggan dalam waktu dalam waktu maksimal satu kali dalam satu minggu kunjungan. Strategi distribusi tersebut digunakan agar suatu produk yang ditawarkan langsung terealisasi sehingga ketersediaan produk di pengecer tetap terjaga (Hartono, 2009).

Secara idealitis, saluran distribusi ditentukan dengan mengeksplorasi keinginan konsumen tentang pelayanan yang membahas, berapa banyak mereka bersedia untuk membayar pada tingkat pelayanan yang diberikan, bagaimana pelayanan dapat diberikan kepada mereka dan biaya dari alternatif saluran distribusi.

Dengan memahami kepuasan klien (pelanggan) adalah penting bagi manajemen, yang dapat menyebabkan loyalitas klien (pelanggan) dan pada gilirannya dapat menciptakan keunggulan kompetitif bagi perusahaan (Harnoto, 2014). Kualitas pelayanan merupakan suatu kinerja yang bergantung pada interaksi manusia dalam pelayanan yang dihadapi dan hasil dari kualitas pelayanan berhubungan dengan proses interaktif antara penyedia jasa dan penerima jasa (Andayani \& Rosinta, 2011).

Kualitas adalah tingkat mutu yang diharapkan dan pengendalian keragaman dalam mencapai mutu tersebut untuk memenuhi kebutuhan konsumen.Untuk dapat memberikan kualitas pelayanan yang baik maka perlu dibina hubungan yang erat antar perusahaan.Untuk itu kualitas merupakan kunci sukses dari suatu organisasi (Laksana, 2008). Jadi kualitas pelayanan adalah anggapan pelanggan mengenai apa-apa yang dirasakan mengenai layanan yang diberikan oleh karyawan terhadap pelanggan.

Hasil penelitian yang dilakukan Parasuraman, Zeithaml, dan Berry terhadap beberapa jenis jasa dan berhasil mengidentifikasi sepuluh faktor utama yang menentukan kualitas jasa. Kesepuluh faktor tersebut meliputi, yakni reliabilitas, daya tanggap, kompetisi, akses, kesopanan, kredibilitas, keamanan, akses komunikasi, kemampuan memahami pelanggan dan bukti fisik. Selanjutnya dirangkum menjadi 5 dimensi yakni, kompetisi, kesopanan, kredibilitas dan keamanan dijadikan satu menjadi jaminan (assurance). Selanjutnya akses komunikasi dan kemampuan memahami pelanggan dijadikan satu menjadi empati 
(Emphaty). Tiga dimensi lainnya adalah reliability, responsiveness dan tangible (Parasuraman, Zeithaml, \& Berry, 1985).

Saluran distribusi adalah serangkaian organisasi yang terkait dalam semua kegiatan yang digunakan untuk menyalurkan produk dan status pemilikannya dari produsen ke konsumen (Laksana, 2008). Selaras dengan pernyataan (Bahtiar \& Rahardja, 2017)saluran distribusi merupakan perantara untuk memindahkan produk atau jasa dari produsen kepada konsumen.

Jadi saluran distribusi adalah suatu proses penyampaian produk dan jasa dari produsen kepada konsumen dengan memilih alternatif saluran pemasaran yang tepat dan menganalisa situasi daerah pemasaran yang akan dipilih

Adanya saluran distribusi akan berimplikasi terhadap konsumen adalah kondisi yang paling ideal adalah ketika memerlukan sesuatu produk, maka informasi tentang produk yang dibutuhkan bisa diperoleh dengan mudah, murah dan menyenangkan (Nitisusastro, 2013).

Kepuasan pelanggan adalah sebagai akumulasi pengalaman dari pelanggan setelah melakukan suatu pembelian dan pengalaman konsumsinya (Andreassen, 1994). Definisi senada dengan yang disampaikan (Hartono, 2009)menunjukkan bahwa kepuasan pelanggan adalah hasil akumulasi dari konsumen atau pelanggan dalam menggunakan produk dan jasa. Oleh karena itu, setiap transaksi atau pengalaman baru, akan memberikan pengaruh terhadap kepuasan pelanggan. Dengan demikian, kepuasan pelanggan mempunyai dimensi waktu karena hasil akumulasi. Karena itu, siapapun yang terlibat dalam urusan kepuasan pelanggan, ia telah melibatkan diri dalam urusan jangka panjang. Upaya memuaskan pelanggan adalah pengalaman panjang yang tidak mengenal batas akhir.

Definisi sebelum bisa dikatakan bahwa kepuasan pelanggan merupakan perasaan puas atau tidak puas darui pelanggan setelah memakai dari sebuah produk dan jasa yang telah dibelinya. Bagi pemasar penting untuk memahami kepuasan klien (pelanggan), karena bisa memunculkan keunggulan kompetitif bagi perusahaan

Memahami kepuasan klien (pelanggan) adalah penting bagi manajemen, yang dapat menyebabkan loyalitas klien (pelanggan) dan pada gilirannya dapat menciptakan keunggulan kompetitif bagi perusahaan (Harnoto, 2014).

Kepuasan pelanggan yang tercipta bisa memberikan beberapa manfaat antara lain, hubungan antara perusahaan dan pelanggan menjadi harmonis, memberikan dasar yang baik bagi pelanggan dalam melakukan pembelian ulang dan terciptanya loyalitas pelanggan, dan membentuk suatu rekomendasi dari mulut ke mulut (word of mouth) yang menguntungkan bagi perusahaan (Tjiptono, 2014). Konsep kepuasan pelanggan dapat dilihat padagambar berikut. 


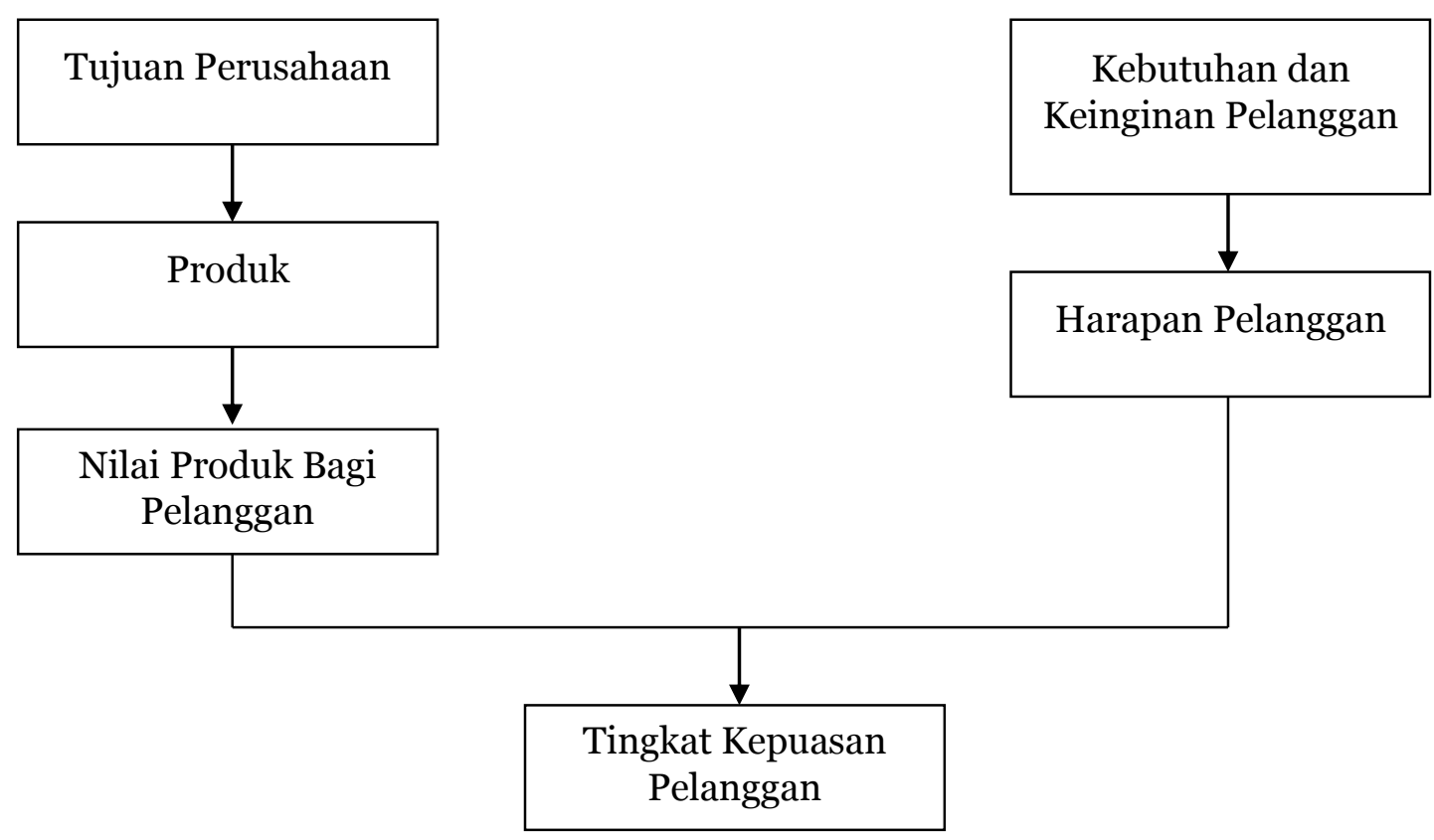

Gambar 1. Konsep Kepuasan Pelanggan (Sujianto, 2014)

Kepuasan pelanggan ditentukan oleh persepsi pelanggan atas performance produk atau jasa dalam memenuhi harapan pelanggan. Kepuasan pelanggan dipengaruhi oleh lima faktor sebagai berikut: (1) kualitas produk; pelanggan puas kalau setelah membeli dan menggunakan produk tersebut, ternyata kualitas produknya baik; (2) harga; pelanggan yang sensitif, biasanya harga murah adalah sumber kepuasan yang penting karena mereka akan mendapatkan value for money yang tinggi; (3) kualitas pelayanan (service quality), bergantung pada tiga hal yaitu: sistem, teknologi, dan manusia; (4) emotional factor, kepuasan pelanggan dapat timbul, misalnya pada saat mengendarai mobil yang memiliki brand image yang baik. Rasa bangga, rasa percaya diri, simbol sukses, bagian dari kelompok orang penting dan sebagainya adalah contoh-contoh emotional value yang mendasari kepuasan pelanggan dan (5) kemudahan, pelanggan akan semakin puas apabila relatif mudah, nyaman dan efisien dalam mendapatkan produk atau pelayanan (Irawan, 1997).

Terdapat beberapa metode yang dapat digunakan dalam mengukur tingkat kepuasan pelanggan (Kotler \& Armstrong, 2008) adalah sebagai berikut: (1) sistem keluhan dan saran, perusahaan menyediakan kartu komentar untuk diisi oleh pelanggannya terkait saran dan keluhan yang ingin disampaikan.; (2) survey kepuasan pelanggan; perusahaan yang responsif mengukur kepuasan pelanggan secara langsung dengan melakukan survei berkala; (3).belanja siluman, perusahaan membayar orang-orang untuk bertindak sebagai pembeli potensial guna melaporkan hasil temuan mereka tentang kekuatan dan kelemahan yang mereka alami ketika membeli produk perusahaan dan produk pesaing dan (4) analisis pelanggan yang hilang, 
perusahaan harus menghubungi para pelanggan yang berhenti membeli atau berganti pemasok untuk mempelajari sebabnya .

Tingkat kepuasan pelanggan secara keseluruhan adalah kombinasi dari tiga parameter, yaitu: biaya yang dikenakan, frekuensi masalah yang dihadapi, dan perilaku pembelian (Tjiptono, 2014). Penelitian ini bertujuan untuk (1) menguji pengaruh signifikan dana Citra perusahaan terhadap Kepuasan Nasabah BPRS Mandiri Mitra Sukses; (2) menguji pengaruh signifikan Kualitas Pelayanan terhadap Kepuasan Nasabah BPRS Mandiri Mitra Sukses dan (3) menguji Saluran Distribusi berpengaruh signifikan terhadap Kepuasan Nasabah BPRS Mandiri Mitra Sukses.

\section{METODE PENELITIAN}

Jenis penelitian menggunakan jenis penelitian kuantitatif, yakni yang berlandaskan pada filsafat positivisme, digunakan untuk meneliti pada populasi atau sampel tertentu, pengumpulan data menggunakan instrumen penelitian, analisis data bersifat kuantitatif/statistik, dengan tujuan untuk menguji hipotesis yang telah ditetapkan(Subagiyo, 2017).

Populasi dalam penelitian ini adalah seluruh nasabah yang memiliki rekening tabungan masa depan. Jumlah populasi yang tidak diketahui secara pasti atau tidak hingga.

Teknik penarikan sampel ini akan dibahas tentang cara pengambilan sampel di lapangan dan ukuran sampel yang dipakai. Isaac dan Michael dalam (Sugiyono, 2015) menyatakan bahwa besarnya jumlah sampel yang diambil dapat ditentukan berdasarkan pada tabel penentuan jumlah sampel dari populasi tertentu yang dikembangkan untuk tingkat kesalahan $1 \%, 5 \%$, dan $10 \%$ berikut:

\section{Tabel 1.}

\section{Penentuan Jumlah Sampel dari Populasi Tertentu}

\section{Keterangan:}

\begin{tabular}{|c|c|c|c|}
\hline \multirow{2}{*}{$\mathbf{N}$} & \multicolumn{3}{|c|}{$\mathbf{s}$} \\
\cline { 2 - 4 } & $\mathbf{1 \%}$ & $\mathbf{5 \%}$ & $\mathbf{1 0 \%}$ \\
\hline 10 & 10 & 10 & 10 \\
100 & 87 & 78 & 73 \\
100000 & 659 & 347 & 270 \\
600000 & 663 & 348 & 270 \\
\cline { 1 - 1 }------ & 663 & 348 & 270 \\
\hline
\end{tabular}

$\mathrm{N} \quad=$ Jumlah Populasi

$\mathrm{s} \quad=$ Taraf Kesalahan (\%) 


\section{7 |Citra Perusahaan, Kualitas Pelayanan dan Saluran Distribusi Terhadap Kepuasan Nasabah}

Sebagaimana populasi dalam penelitian ini adalah jumlah yang tidak diketahui dengan pasti pada taraf kesalahan $5 \%(0,05)$ sehingga jumlah sampel yang dapat ditentukan dalam penelitian ini adalah 348 responden.Teknik penarikan sampel yang digunakan adalah purposive sampling penarikan sampel didasari kriteria yaitu :

1. Nasabah memiliki rekening tabungan masa depan.

2. Nasabah penabung yang telah menabung lebih dari 3 bulan

\section{Tabel 2}

\section{Desain Kosntruk Kuesioner}

\begin{tabular}{|c|c|c|c|c|}
\hline $\begin{array}{c}\text { No } \\
\text {. }\end{array}$ & Variabel & Dimensi & Indikator & $\begin{array}{l}\text { No. } \\
\text { Item }\end{array}$ \\
\hline \multirow[t]{6}{*}{1} & \multirow{6}{*}{$\begin{array}{c}\text { Citra } \\
\text { Perusahaa } \\
\text { n }\left(\mathrm{X}_{1}\right)\end{array}$} & Lambang (X1.1) & $\begin{array}{l}\text { 1. BPRS Mitra Sukses mempunyai simbol } \\
\text { khusus sebagai bank syariah. }\end{array}$ & 1 \\
\hline & & Media (X1.2) & $\begin{array}{l}\text { 2. } \quad \text { BPRS Mitra Sukses menjadi tujuan } \\
\text { menabung dan pembiyaan bagi masyarakat. }\end{array}$ & 2 \\
\hline & & \multirow{3}{*}{ Suasana (X1.3) } & 3. Kantor Bank yang bersih dan rapi. & \multirow{3}{*}{$\begin{array}{c}3 \mathrm{~s} / \mathrm{d} \\
5\end{array}$} \\
\hline & & & $\begin{array}{l}\text { 4. Ruang tunggu lobi yang tertata dengan } \\
\text { rapi. }\end{array}$ & \\
\hline & & & $\begin{array}{l}5 . \quad \text { Lokasi kantor bank yang aman dan nyaman } \\
\text { bagi masyarakat. }\end{array}$ & \\
\hline & & Peristiwa (X1.4) & $\begin{array}{l}\text { 6. Dokumen dan laporan keuangan yang } \\
\text { tertata dengan rapi. }\end{array}$ & 6 \\
\hline \multirow[t]{9}{*}{2} & \multirow{9}{*}{$\begin{array}{c}\text { Kualitas } \\
\text { Pelayanan } \\
\left(\mathrm{X}_{2}\right)\end{array}$} & \multirow{2}{*}{$\begin{array}{l}\text { Bukti Langsung } \\
\text { (X2.1) }\end{array}$} & $\begin{array}{l}\text { 7. Peralatan kantor yang modern dan } \\
\text { memadai }\end{array}$ & \multirow[t]{2}{*}{$\begin{array}{c}7 \mathrm{~s} / \mathrm{d} \\
8\end{array}$} \\
\hline & & & $\begin{array}{l}\text { 8. Brosur dan formulir yang lengkap dan } \\
\text { menarik }\end{array}$ & \\
\hline & & \multirow{3}{*}{$\begin{array}{l}\text { Kehandalan } \\
\text { (X2.2) }\end{array}$} & $\begin{array}{l}\text { 9. Menepati apa yang telah dijanjikan dalam } \\
\text { pelayanan. }\end{array}$ & \multirow[t]{3}{*}{$\begin{array}{c}9 \mathrm{~s} / \mathrm{d} \\
11\end{array}$} \\
\hline & & & $\begin{array}{l}\text { 10. Memberikan jawaban dengan baik dan } \\
\text { memuaskan. }\end{array}$ & \\
\hline & & & 11. Keakuratan informasi data. & \\
\hline & & \multirow{2}{*}{$\begin{array}{l}\text { Daya Tanggap } \\
\text { (X2.3) }\end{array}$} & 12. Memahami apa yang diinginkan pelanggan. & \multirow{2}{*}{$\begin{array}{c}12 \\
s / d \\
13\end{array}$} \\
\hline & & & $\begin{array}{l}\text { 13. Pelayanan secara maksimal terhadap } \\
\text { pelanggan yang komplain. }\end{array}$ & \\
\hline & & \multirow[t]{2}{*}{ Jaminan (X2.4) } & $\begin{array}{l}\text { 14. Pegawai memiliki pengetahuan dalam } \\
\text { pelayanan. }\end{array}$ & \multirow{2}{*}{$\begin{array}{c}14 \\
s / d \\
16\end{array}$} \\
\hline & & & 15. Pegawa memiliki sikap ramah dan santun. & \\
\hline
\end{tabular}




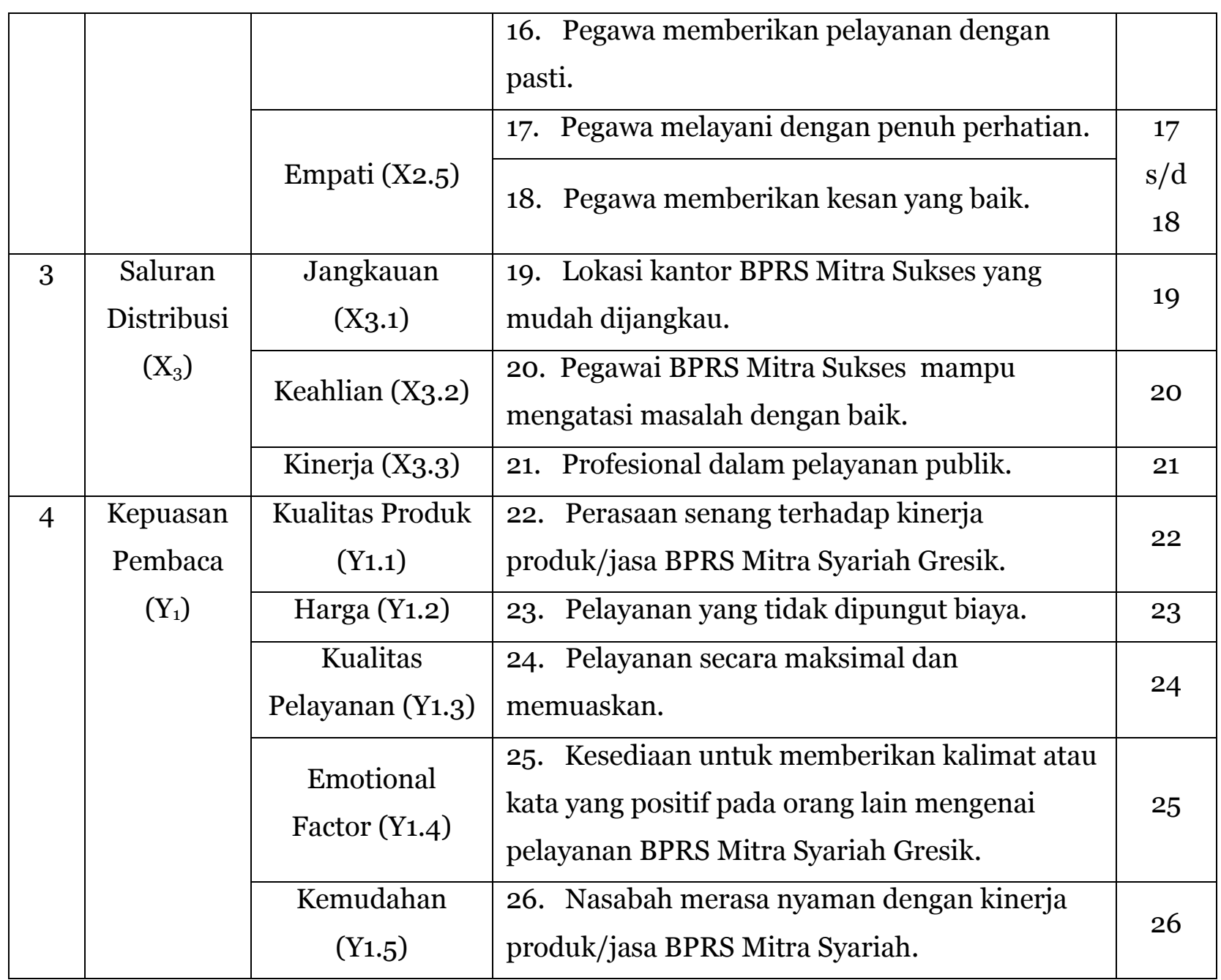

Setiap variabel dijabarkan dalam bentuk pertanyaan dengan pengukuran skala likert. Jawaban atas item pernyataan dalam kuesioner memiliki tingkatan atau rank positif sampai negatif. Dengan pilihan jawaban sebagai berikut yaitu (1) sangat setuju; (2) setuju; (3) raguragu/netral; (4) tidak Setuju dan (5) sangat tidak setuju.

Teknik analisis data yang digunakan dalam penelitian ini adalah "Regresi Linear Berganda," yakni pengaruh variabel independen (citra perusahaan, kualitas pelayanan, dan saluran distribusi) dengan variabel dependen (kepuasan pelanggan).

Bentuk umum dari model analisis regresi linear berganda adalah:

$\mathrm{Y}=\mathrm{b}_{\mathrm{o}}+\mathrm{b}_{1} \mathrm{X}_{1}+\mathrm{b}_{2} \mathrm{X}_{2}+\mathrm{b}_{3} \mathrm{X}_{3}$

Keterangan:

Y

$\mathrm{X}_{1}$

= Kepuasan Pelanggan.

$\mathrm{X}_{1} \quad=$ Citra Perusahaan.

$\mathrm{X}_{2} \quad=$ Kualitas Pelayanan.

$\mathrm{X}_{3} \quad=$ Saluran Distribusi.

$b_{o} b_{1} b_{2} b_{3} \quad=$ Koefisien Regresi. 
289 |Citra Perusahaan, Kualitas Pelayanan dan Saluran Distribusi Terhadap Kepuasan Nasabah

\section{HASIL DAN PEMBAHASAN}

Hasil pengolahan data menggunakan alat pengolah statistik SPSS 20.o for Windows dapat ditampilkan sebagai berikut:

Tabel 3

Hasil Perhitungan Regresi Linear Berganda

\begin{tabular}{cc}
\hline Variabel & Koefisien \\
\hline Konstanta & 1,356 \\
Citra Perusahaan (X1) & 0,166 \\
Kualitas Pelayanan (X2) & 0,329 \\
Saluran Distribusi (X3) & 0,231 \\
\hline
\end{tabular}

Sumber: Data diolah

Berdasarkan tabel 3, maka diperoleh persamaan regresi linear berganda sebagai berikut:

$\mathrm{Y}=1,356+0,166 \mathrm{X}_{1}+0,329 \mathrm{X}_{2}+0,231 \mathrm{X}_{3}+\mathrm{e}$

Interpretasi pengaruh perubahan masing-masing variabel yang ditentukan oleh nilai beta dari persamaan hasil regresi berganda di atas adalah nilai konstanta persamaan regresi bertanda positif 1,356 menunjukkan Peningkatan Kepuasan Nasabah, yaitu pada saat variabel bebas (Citra Perusahaan, Kualitas Pelayanan dan Saluran Distribusi) mempunyai nilai nol atau tidak ada, maka Kepuasan Nasabah BPRS Mitra Sukses Gresik adalah 1,356 satuan. Koefisien regresi menunjukkan besarnya perubahan yang terjadi pada variabel tergantung (Kepuasan Pelanggan) bila variabel bebas berubah satu satuan. Koefisien regresi o,166 menyatakan bahwa setiap penambahan satu satuan variabel Citra Perusahaan maka Kepuasan Nasabah BPRS Mitra Sukses Gresik akan meningkat sebesar 0,166 satu satuan dengan asumsi variabel lain tetap.

Koefisien regresi menunjukkan besarnya perubahan yang terjadi pada variabel tergantung (Kepuasan Nasabah) bila variabel bebas berubah satu satuan. Koefisien regresi o,329 menyatakan bahwa setiap penambahan satu satuan variabel Kualitas Pelayanan maka Kepuasan Nasabah BPRS Mitra Sukses Gresik akan meningkat sebesar 0,329 satu satuan dengan asumsi variabel lain tetap. Koefisien regresi menunjukkan besarnya perubahan yang terjadi pada variabel tergantung (Kepuasan Pelanggan) bila variabel bebas berubah satu satuan. Koefisien regresi o,231 menyatakan bahwa setiap penambahan satu satuan variabel saluran disribusi maka Kepuasan Nasabah BPRS Mitra Sukses Gresik akan meningkat sebesar o,243 satu satuan dengan asumsi variabel lain tetap.

Standardized Coefficients nilai standardized coefficients masing-masing variabel bebasnya yaitu citra perusahaan sebesar 0,160, kualitas pelayanan sebesar 0,318 dan saluran Distribusi sebesar 0,244. Untuk mengetahui variabel bebas manakah di antara ketiga variabel tersebut yang mempunyai pengaruh dominan terhadap Kepuasan Nasabah BPRS Mitra Sukses 
Gresik adalah dengan melihat nilai standardized coefficients-nya. Dari tabel 3. dapat kita lihat bahwa Kualitas Pelayanan mempunyai nilai yang paling besar yaitu sebesar 0,318; sehingga dapat disimpulkan bahwa Kualitas Pelayanan mempunyai pengaruh yang paling dominan terhadap Kepuasan Nasabah BPRS Mitra Sukses Gresik daripada variabel bebas lainnya.

\section{Pengaruh Citra Perusahaan $\left(\mathrm{X}_{1}\right)$ terhadap Kepuasan Nasabah BPRS Mitra Sukses Gresik (Y)}

Berdasarkan hasil perhitungan uji t antara Citra Perusahaan terhadap Kepuasan Nasabah BPRS Mitra Sukses Gresik yaitu: Citra Perusahaan $\left(\mathrm{X}_{1}\right)$, diperoleh t hitung adalah 3,081 $>\mathrm{t}_{\alpha / 2}$ tabel 1,9668 dengan nilai signifikansi t $0,00<0,05$; berarti berada dalam daerah penolakan Ho atau pada daerah penerimaan H1. Hal ini menunjukkan bahwa Citra Perusahaan berpengaruh signifikan terhadap Nasabah BPRS Mitra Sukses Gresik.

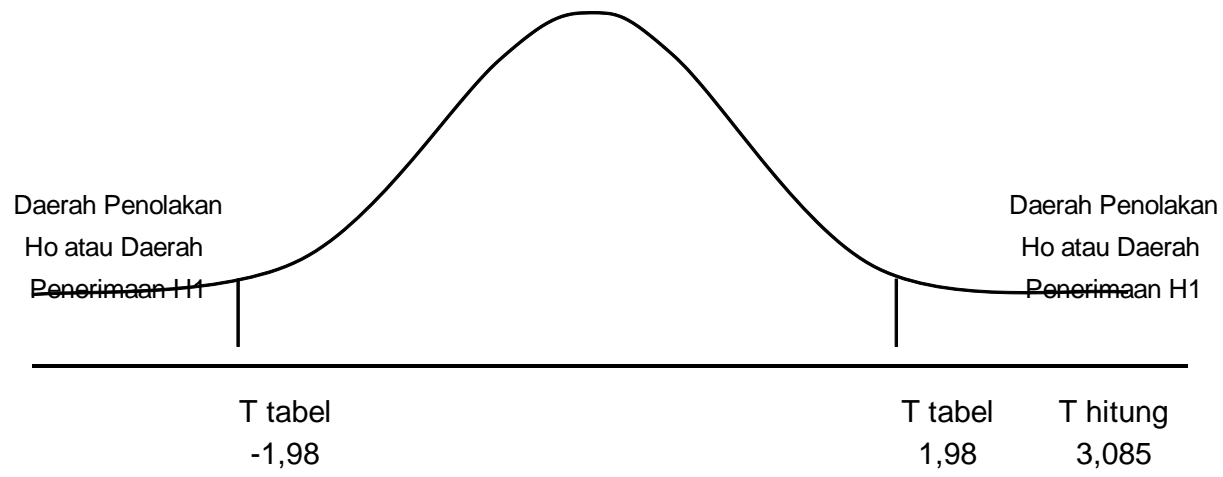

\section{Gambar 2. Pengaruh Citra Perusahaan Terhadap Kepuasan Nasabah}

Secara teoritis dijelaskan bahwa citra perusahaan adalah persepsi masyarakat terhadap perusahaan atau produknya (Kotler, 2012) Citra perusahaan yang kuat adalah apabila namanya dikenal luas dan organisasi tersebut mempunyai reputasi yang luar biasa (Jasfar, 2005). Apabila suatu organisasi sangat terkenal, tetapi tidak dipercaya, maka organisasi tidak akan memiliki citra yang kuat. Sama halnya, dia tidak akan mempunyai citra yang kuat apabila dipercaya hanya oleh sekelompok kecil orang. Citra perusahaan bisa dikatakan baik apabila citra tersebut dibangun oleh apa yang pelanggan atau masyarakat rasakan dan ketahui mengenai perusahaan.

Hal ini juga didukung oleh hasil penelitian yang dilakukan (Safitri, Rahayu, \& Indrawati, 2016), yang menyatakan bahwa citra perusahaan berpengaruh signifikan terhadap kepuasan pelanggan. Tetapi tidak selaras (Moorthy et al., 2018) yang menjelaskan bahwa citra perusahaan tidak memiliki hubungan dengan kepuasan pelanggan terhadap penyedia layanan internet di Malaysia. 
291 |Citra Perusahaan, Kualitas Pelayanan dan Saluran Distribusi Terhadap Kepuasan Nasabah

\section{Pengaruh Kualitas Pelayanan $\left(X_{2}\right)$ terhadap Kepuasan Nasabah BPRS Mitra Sukses Gresik yaitu (Y)}

Output dari uji t menunjukkan bahwa Kualitas Pelayanan $\left(\mathrm{X}_{2}\right)$, diperoleh $\mathrm{t}$ hitung adalah 5,731 $>t_{\alpha / 2}$ tabel 1,980 dengan nilai signifikansi $t$ 0,002 > 0,05; berarti berada dalam daerah penerimaan $\mathrm{H} 1$ atau pada daerah penolakan Ho. Hal ini menunjukkan bahwa faktor Kualitas Pelayanan berpengaruh signifikan terhadap Kepuasan Nasabah BPRS Mitra Sukses Gresik.

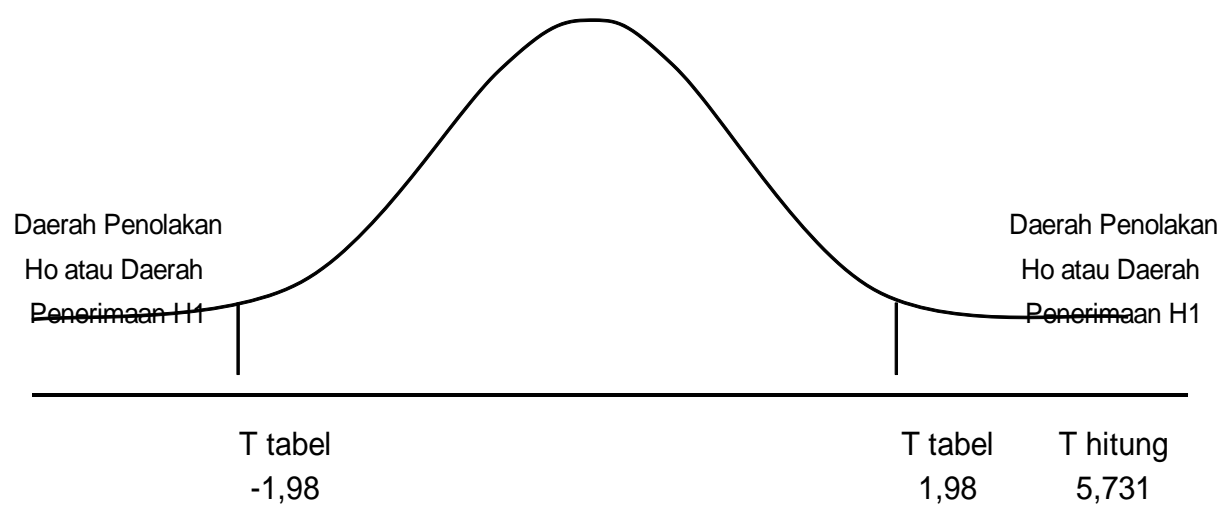

Gambar 3. Pengaruh Kualitas Pelayanan Terhadap Kepuasan Nasabah

Hasil penelitian ini selaras dengan hasil penelitian (Olatokun \& Ojo, 2014) mengenai pengaruh kualitas pelayanan pelanggan operator ponsel terhadap kepuasan pelanggan di Nigeria. Diperkuat oleh penelitian yang dilakukan oleh (Ruiz Díaz, 2017) pengaruh kualitas pelayanan pelanggan operator ponsel GSM terhadap kepuasan pelanggan di Peru. Namun, tidak sesuai dengan penelitian yang dilakukan oleh (Kristanto, 2015) yang menyatakan bahwa kualitas layanan tidak memiliki pengaruh terhadap kepuasan pelanggan pada cafe One Eighteenth Coffee

Berdasarkan hasil yang diperoleh, selaras dengan teori kualitas pelayanan merupakan harapan atas mutu dan keragaman untuk mengendalikannya dalam pemenuhan kebutuhan konsumen. Agar kualitas pelayanan yang didapatkan baik, perlu dibina hubungan erat antar karyawan di dalam perusahaan (Subagiyo, 2013). Jadi kualitas pelayanan adalah anggapan pelanggan mengenai apa-apa yang dirasakan mengenai layanan yang diberikan oleh karyawan terhadap pelanggan.

\section{Pengaruh Saluran Distribusi $\left(X_{3}\right)$ Terhadap Kepuasan Nasabah BPRS Mitra Sukses Gresik (Y)}

Perhitungan uji t menunjukkan bahwa Saluran Distribusi $\left(\mathrm{X}_{3}\right)$, diperoleh $\mathrm{t}$ hitung adalah 4,727> $t_{\alpha / 2}$ tabel 1,980 dengan nilai signifikansi t $0,00<0,05$; berarti berada dalam daerah penerimaan H1 atau pada daerah penolakan Ho. Hal ini menunjukkan bahwa Saluran Disstribusi berpengaruh signifikan terhadap Kepuasan Nasabah BPRS Mitra Sukses Gresik. 


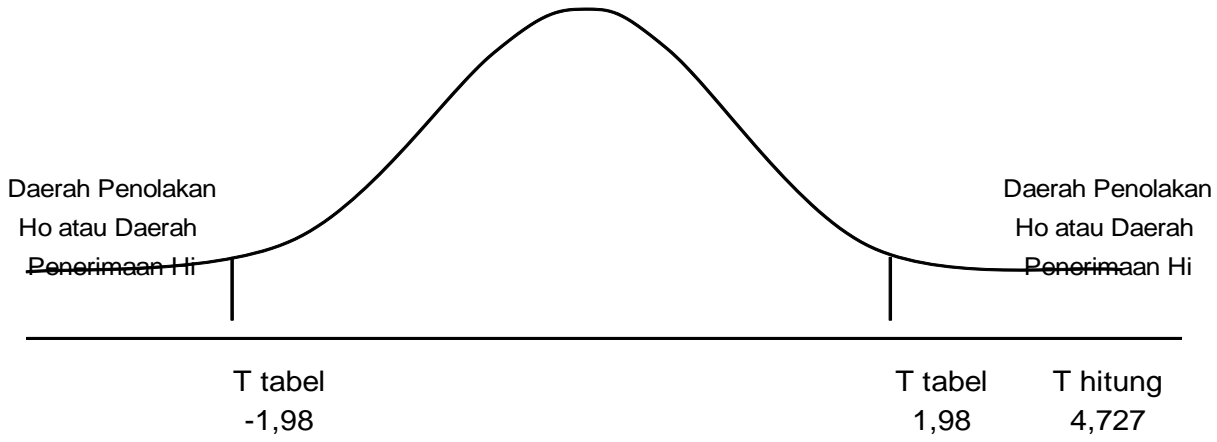

\section{Gambar 4. Pengaruh Saluran Distribusi Terhadap Kepuasan Nasabah}

Dari hasil di atas dapat disimpulkan bahwa semua faktor, yaitu Citra Perusahaan $\left(\mathrm{X}_{1}\right)$, Kualitas Pelayanan $\left(\mathrm{X}_{2}\right)$ dan Saluran Distribusi $\left(\mathrm{X}_{3}\right)$ berpengaruh signifikan terhadap Kepuasan Nasabah BPRS Mitra Sukses Gresik sesuai dengan hipotesis yang diajukan semula.

Hasil Penelitian ini sesuai teori yang disampaikan (Kotler \& Armstrong, 2008) yaitu suatu perusahaan dapat mencapai keunggulan bersaing melalui cara mereka dalam merancang saluran distribusi. (Asir, 2017), Saluran distribusi merupakan suatu struktur yang menggambarkan alternatif saluran yang dipilih dan menggambarkan situasi pemasaran yang berbeda oleh berbagai perusahaan.

Hasil ini didukung oleh penelitian yang dilakukan oleh (Tanjaya \& Wijaya, 2019) yang menyatakan saluran distribusi berpengaruh signifikan terhadap kepuasan pelanggan dan (Anisa \& Rushadiyati, 2018) yang mengatakan bahwa Saluran distribusi berpengaruh terhadap Kepuasan Pelanggan agen sancu creative Indonesia.

\section{KESIMPULAN}

Berdasarkan pembahasan di atas, maka dapat diambil simpulan sebagai berikut: (1) citra perusahaan berpengaruh signifikan terhadap kepuasan nasabah BPRS Mitra Sukses Gresik; (2) kualitas pelayanan berpengaruh signifikan terhadap kepuasan nasabah BPRS Mitra Sukses Gresik dan (3) saluran distribusi berpengaruh signifikan terhadap kepuasan nasabah BPRS Mitra Sukses Gresik. Rekomendasi atas penelitian ini antara lain: (1) semua variabel bebas yang digunakan berpengaruh signifikan terhadap Kepuasan Nasabah BPRS Mitra Sukses Gresik, maka : "Disarankan agar pihak Kepuasan Nasabah BPRS Mitra Sukses Gresik lebih melakukan inovasi dan kreasi terhadap sales promotion yang lebih menarik nasabah, agar tetap menjadi nasabah yang setia atau loyal"; (2) nilai koefisien determinasi menunjukkan nilai yang rendah yaitu sebesar 35,3\%, sedangkan sisanya dipengaruhi oleh variabel lain di luar variabel yang digunakan dalam persamaan tersebut, oleh karena itu disarankan bagi peneliti selanjutnya untuk menambahkan faktor lain di luar faktor yang digunakan yang menyangkut kepuasan nasabah serta lebih memperhatikan $3 p$ yang lain yaitu produk (jenis simpanan atau tabungan yang lebih variatif), lokasi dan promosi. 


\section{DAFTAR PUSTAKA}

Alma, B. (2013). Manajemen Pemasaran dan Pemasaran Jasa (Revisi). Bandung: Alfabeta.

Andayani, D., \& Rosinta, F. (2011). Pengaruh Kualitas Layanan terhadap Kepuasan Pelanggan dalam Membentuk Loyalitas Pelanggan. Jurnal Ilmu Administrasi Dan Birokrasi, 17(2). https://doi.org/10.20476/jbb.v17i2.632

Andreassen, T. W. (1994). Satisfaction, Loyalty and Reputation as Indicators of Customer Orientation in the Public Sector. International Journal of Public Sector Management. https://doi.org/10.1108/09513559410055206

Anisa, \& Rushadiyati. (2018). Pengaruh Kualitas Pelayanan Dan Saluran Distribusi Terhadap Kepuasan Agen Sancu Creative Indonesia. Jurnal Administrasi Dan Manajemen, 11(1).

ASIR, M. (2017). Pengaruh Saluran Distribusi, Kualitas Produk Dan Kebijakan Harga Terhadap Kepuasaan Pelanggan (Studi Kasus PT. Centa Brasindo Abadi). Jurnal Pasca Unhas.

Bahtiar, A., \& Rahardja, E. (2017). Pengaruh Brand Equity, Harga Dan Distribusi Terhadap Keputusan Pembelian Vape (Studi PadaVape Store 5Time). Bahtiar Ahmad, Edy Rahardja, 6(4).

Bajra, B., Arifin, Z., \& Sunarti. (2015). Analisis Pengaruh CSR (Corporate Social Responsibility) Terhadap Citra Perusahaan ( Studi Kasus Pada Masyarakat Sekitar PT . Adaro Indonesia di Kalimantan Selatan ). Jurnal Administrasi Bisnis(JAB), $30(1)$. https://doi.org/10.3892/or.2015.4130

Harnoto, F. (2014). Strategi Kepuasan Pelanggan Dalam Mempertahankan Dan Meningkatkan Loyalitas Pelanggan. Jurnal Ekonomi Manajemen Dan Akuntansi, 21(36).

Hartono, I. (2009). 10 Prinsip Kepuasan Pelanggan. Jakarta: PT. Elex Media Komputindo. https://doi.org/10.1080/00074918.2013.809844

Haryono, T. (2015). Pentingnya Menjaga Dan Meningkatkan Hubungan Baik Dengan Konsumen Dalam Masa Krisis. JEJAK: Jurnal Ekonomi Dan Kebijakan, 3(1). https://doi.org/10.15294/jejak.v3i1.4666

Irawan, Faried Wijaya, S. (1997). Prinsip-Prinsip Pemasaran (2nd ed.). Yogyakarta: BPFE.

Jasfar, F. (2005). Manajemen jasa: pendekatan terpadu. Bogor: Ghalia Indonesia.

Kotler, P. (2012). Marketing management/Philip Kotler, Kevin Lane Keller. Pearson Education International. 
Kotler, P., \& Armstrong, G. (2008). Principles of Marketing 7e (B. Sabran, Ed.). Jakarta: Erlangga.

Kristanto, J. O. (2015). Pengaruh Kualitas Layanan, Kualitas Produk, Dan Harga Terhadap Kepuasan Pelanggan Di Cafe One Eighteenth Coffee. Jurnal Manajemen, 3(4).

Laksana, F. (2008). Manajemen Pemasaran. Yogyakarta: Graha Ilmu.

Moorthy, K., Chun T’ing, L., Ai Na, S., Tze Ching, C., Yuin Loong, L., Sze Xian, L., \& Wei Ling, T. (2018). Corporate image no longer leads to customer satisfaction and loyalty: a Malaysian perspective. International Journal of Law and Management, 6o(4). https://doi.org/10.1108/IJLMA-04-2017-0082

Nitisusastro, M. (2013). Perilaku Konsumen Dalam Perspektif Kewirausahaan. Bandung: CV. AlfaBeta.

Olatokun, W. M., \& Ojo, F. O. (2014). Influence of service quality on consumers' satisfaction with mobile telecommunication services in Nigeria. Information Development, 32(3). https://doi.org/10.1177/0266666914553316

Parasuraman, A., Zeithaml, V. A., \& Berry, L. L. (1985). A conceptual model of service quality and its implication for future research. Journal of Marketing. https://doi.org/10.2307/1251430

Ruiz Díaz, G. (2017). The influence of satisfaction on customer retention in mobile phone market. Journal of Retailing and Consumer Services, 36. https://doi.org/10.1016/j.jretconser.2017.01.003

Safitri, F., Rahayu, M., \& Indrawati, N. K. (2016). Pengaruh Kualitas Pelayanan dan Citra Perusahaan Terhadap Kepuasan Pelanggan dan Loyalitas Pelanggan Service Center [ Studi Pada Pelanggan Samsung Service Center di Kota Malang ]. Jurnal Ekonomi Bisnis, 21(1).

Soemirat, S., \& Ardianto, E. (2007). Dasar-Dasar Public Relation. Bandung: PT. Remaja RosdaKarya.

Subagiyo, R. (2013). Pengaruh Kualitas Pelayanan, Bauran pemasaran, dan Kepuasan Nasabah Terhadap Loyalitas Nasabah Pada BPRS Mitra Syariah di Gresik. Sunan Ampel.

Subagiyo, R. (2017). Metode Penelitian Ekonomi Islam: Konsep dan Penerapan. Jakarta: Alim's Publishing. 
295 |Citra Perusahaan, Kualitas Pelayanan dan Saluran Distribusi Terhadap Kepuasan Nasabah

Subagiyo, R., \& Adlan, M. A. (2017). Pengaruh Service Quality, Marketing Mix dan Kepuasan Mahasiswa terhadap Customer Loyalty. Jurnal Ekonomi Modernisasi, 3(1). https://doi.org/10.21067/jem.v13i1.1567

Sugiyono. (2015). Metode Penelitian Kombinasi (Mixed Methods). In Bandung: Alfabeta. Jakarta: Alfabeta.

Sujianto, A. E. ; R. S. (2014). Membangun loyalitas nasabah. Yogyakarta: Lentera Kreasiondo. Tanjaya, V., \& Wijaya, W. (2019). Pengaruh Saluran Distribusi Dan Personal Selling Terhadap Kepuasan Pelanggan Pada PT. Bilah Baja Makmur Abadi. Jurnal Manajemen, 5(2).

Tjiptono, F. (2014). Pemasaran Jasa. In CV. Andi Offset. Yogyakarta. https://doi.org/10.1177/0300985809357753 